\title{
STRATEGI PENGEMBANGAN INKUBATOR BISNIS SEBAGAI LEMBAGA PENDAMPINGAN PERUSAHAAN PEMULA: STUDI KASUS INKUBATOR BISNIS IPB
}

\section{THE DEVELOPMENT STRATEGY OF BUSINESS INCUBATOR AS A NEWBIE STARTER COMPANY: CASE STUDY OF IPB BUSINESS INCUBATOR}

\author{
Heriyanto S Soba $^{*}$, Rokhani Hasbullah ${ }^{* * *}$, dan Nunung Nuryartono ${ }^{* * *}$ \\ *) Suara Pembaharuan \\ Jl. Jend. Gatot Subroto Kav. 35-36, Jakarta 12950 \\ **) Departemen Teknik Mesin dan Biosistem, Fakultas Teknologi Pertanian, Institut Pertanian Bogor \\ Kampus IPB Darmaga, Jl. Lingkar Akademik, Jawa Barat 16680 \\ $\left.{ }^{* * *}\right)$ Departemen Ilmu Ekonomi, Fakultas Ekonomi dan Manajemen, Institut Pertanian Bogor \\ Jl. Agatis Kampus IPB Darmaga, Bogor 16680
}

\begin{abstract}
Business Incubator is a model in growing technology-based entrepreneurship. Compared with the other countries, the business incubator in Indonesia has not been well developed. In fact, the contribution of the business incubator is significant for the successes of the entrepreneurs and the economy in general. This study aimed to analyze the development strategy of business incubators (IncuBie) of IPB by analyzing the internal (Internal Factor Evaluation/IFE) and external (External Factor Evaluation/EFE) factors. This study applied SWOT analysis (Strengths-WeaknessesOpportunities-Threats), and determined the alternative development strategy using Quantitative Strategic Planning Matrix (QSPM). The SWOT analysis showed four alternative development strategies. Meanwhile, the QSPM matrix analysis showed that an interesting strategy to be selected from various strategic alternatives that are available is by increasing the support to the business incubator through the implementation of regulation and provision of particular financing scheme based on its performance and services to the tenants. This strategy managed a number of strengths to take advantage of the existing opportunities (strengths-opportunities/SO) with the highest total attractive score (STAS).
\end{abstract}

Keywords: business incubator, IFE, EFE, SWOT, QSPM

\begin{abstract}
Abstrak: Inkubator bisnis merupakan salah satu model dalam menumbuhkan wirausaha berbasis teknologi. Dibandingkan dengan negara lain, inkubator bisnis di Indonesia belum berkembang dengan baik. Padahal, kontribusi inkubator bisnis cukup signifikan dalam keberhasilan wirausaha dan perekonomian secara umum. Penelitian ini bertujuan untuk menganalisis strategi pengembangan inkubator bisnis (IncuBie) IPB dengan menganalisis analisis faktor internal (Internal Factor Evaluation/IFE) dan eksternal (External Factor Evaluation/EFE). Metode yang digunakan adalah analisis SWOT (Strengths-Weakness-Opportunities-Threats) dan Quantitative Strategic Planning Matrix (QSPM). Analisis SWOT menghasilkan empat alternatif strategi pengembangan inkubator bisnis IPB. Hasil analisis matriks QSPM menunjukkan bahwa strategi utama dari empat alternatif strategi yang diperoleh adalah mengelola sejumlah kekuatan untuk memanfaatkan peluang yang ada (strengths-opportunities/SO) dengan nilai daya tarik (sum total attractive score/STAS) tertinggi. Strategi tersebut adalah meningkatkan implementasi regulasi dan skema pembiayaan khusus bagi inkubator bisnis dengan kinerja dan pelayanan yang baik. Strategi ini menekankan pentingnya implementasi regulasi dan pendanaan untuk mendorong perkembangan inkubator bisnis. Untuk penelitian lebih lanjut disarankan mengkaji efektivitas regulasi yang ada dan mendalami skema pendanaan inkubator bisnis.
\end{abstract}

Kata kunci: inkubator bisnis, IFE, EFE, SWOT, QSPM

\footnotetext{
${ }^{1}$ Alamat Korespondensi:

Email: herisoba@yahoo.com
} 


\section{PENDAHULUAN}

Upaya mendorong kewirausahaan di Indonesia menghadapi sejumlah kendala dan tantangan. Menurut Goenawan dan Ari (2015) beberapa permasalahan yang dihadapi tersebut diantaranya adalah kualitas sumber daya manusia (SDM), manajemen, penguasaan teknologi, modal, daya saing, dan produktivitas. Inkubator bisnis merupakan salah satu model dalam menumbuhkan wirausaha berbasis teknologi. Pendampingan pengusaha pemula berbasis teknologi (PPBT) melalui inkubator bisnis dilakukan secara intensif, didukung fasilitas, akses dana dan jaringan. Purwadaria (2012) menjelaskan proses inkubasi bisnis mempunyai keunggulan antara lain: (1) pendampingan intensif dan terus menerus dalam waktu 2-3 tahun, (2) pendampingan orang per orang untuk menyelesaikan permasalahan, (3) pendampingan dilengkapi dengan pelayanan dan fasilitas pendukung $7 \mathrm{~S}$ (space/tempat; shared/fasilitas bersama seperti pilot plant, peralatan dan laboratorium; service/aneka ragam konsultasi; support/dukungan dan akses; skill development/ bimbingan teknis; seed capital/pendanaan;dan synergy/sinergi), (4) keberhasilan tinggi di atas 50\% dibandingkan tanpa inkubasi (dibawah 10\%), dan (5) perkembangan wilayah pemasaran. Hasbullah (2015) menegaskan bahwa model inkubasi yang paling efektif untuk program inkubasi UMKM pangan adalah model pendampingan partisipatif.
Keberadaan inkubator bisnis sangat penting untuk mendorong dan mendampingi calon wirausahawan serta berkontribusi dalam menggerakkan perekonomian. Bruneel (2012) menjelaskan aktivitas inkubator mempunyai dampak ekonomi di Brazil. Pada 2011, Brazilian Association of Science Parks and Business Incubators (Anprotec) mencatat ada 384 inkubator bisnis, sebanyak 2.640 perusahaan telah melakukan inkubasi, dan 2.509 sudah lulus dari proses inkubasi. Aktivitas inkubator dan perusahaan itu menampung 45.599 pekerja dengan penjualan kotor 5 miliar Real Brasil atau setara 20 triliun Rupiah.

Data Japan-ASEAN Cooperation \& KemenkopUKM (2012) menunjukkan bahwa hingga tahun 2012, jumlah inkubator bisnis di Indonesia baru tercatat 75 unit. Jumlah ini di bawah Thailand yang sudah mencapai 89 unit dan Singapura mencapai 120 unit. Padahal, Indonesia sudah merintis inkubator bisnis sejak 1994, sedangkan Singapura baru tahun 1996 dan Thailand sejak 2005 lalu. Kajian Bank Indonesia (BI) pada 2006 menyebutkan pada tahun 2005, Indonesia memiliki 50 inkubator bisnis yang dikelola pemerintah, perguruan tinggi, dan swasta. Tabel 1 menunjukkan perkembangan inkubator bisnis di Indonesia, Singapura, Thailand, dan Jepang pada tahun 2012.

Tabel 1. Perbandingan inkubator bisnis ASEAN dengan Jepang

\begin{tabular}{lcccc}
\hline \multicolumn{1}{c}{ Kondisi dan dukungan } & Jepang & Singapura & Thailand & Indonesia \\
\hline Keadaan Umum & 1986 & 1996 & 2005 & 1994 \\
Tahun mulai & 190 & 120 & 89 & 75 \\
Jumlah inkubator & 2375 & 1800 & 412 & 400 \\
Jumlah wirausaha baru yang lulus & 120,05 & 5,08 & 68,9 & 240 \\
Jumlah penduduk (juta) GDP x 1000 USD/capita & 36,2 & 60,9 & 10,0 & 5,0 \\
Dukungan Pemerintah & & & Ada & Tidak langsung, melalui \\
Operasional tahunan inkubator & Ada & Ada & & lembaga induk \\
& & & Ada & Belum ada yang spesifik \\
Dana inovasi teknologi wirausaha baru & Ada & Ada & Ada & Belum ada \\
Dana hibah pertumbuhan awal \& investasi & Ada & Ada & Ada & Belum ada Belum ada \\
Modal wirausaha baru & Ada & Ada & Belum ada & Belum ada Belum ada \\
Insentif pajak & Ada & & \\
\hline
\end{tabular}


Gambaran dan data Tabel 1 memperjelas bahwa inkubator bisnis di Indonesia membutuhkan strategi khusus agar bisa berkembang dengan baik. Hal itu sangat diperlukan karena organisasi inkubator bisnis akan berperan dalam mendampingi PPBT dan mendorong iklim wirausaha yang baik. Ada sejumlah faktor yang menjadi tantangan dankendala perkembangan inkubator bisnis, seperti status, komitmen lembaga pendiri atau pemilik inkubator bisnis, dana, dan minimnya tenaga pengelola (manajerial) yang berkarya secara penuh. Di sisi lain, ada juga sejumlah peluang dan kekuatan yang bisa mendorong perkembangan inkubator bisnis. Dewi (2012) menjelaskan belum adanya sinergisme lembaga riset (perguruan tinggi), juga belum ada keterkaitan (link) dengan inkubator bisnis, serta banyaknya incubator bisnis yang mengalami stagnasi. Studi yang dilakukan Tietz (2015) di Brasil menjelaskan ada banyak celah yang belum dieksplorasi peneliti, seperti karakteristik internal atau keterkaitan antara bisnis inkubator dengan triple helix. Kolaborasi triple helix, yakni akademisi, bisnis atau pengusaha dengan pemerintah sangat diperlukan.

Secara umum, kebijakan yang mengatur dan mendukung perkembangan inkubator bisnis sudah baik, seperti Undang-Undang Nomor 20 Tahun 2008 tentang Usaha Mikro, Kecil dan Menengah (UMKM) yang sudah menyinggung perlunya kehadiran inkubator bisnis sebagai bagian dari dukungan kelembagaan terhadap UMKM. Hal itu diperjelas lagi melalui Peraturan Presiden (Perpres) 27/2013 tentang Pengembangan Inkubator Wirausaha yang menegaskan pentingnya pengembangan inkubator bisnis dari tingkat pusat hingga daerah.

Sebelum aturan-aturan tersebut terbit, sejumlah perguruan tinggi, lembaga pemerintah, dan swasta sudah merintis inkubator bisnis. Salah satu perguruan tinggi yang menjadi perintis inkubator bisnis sejak 1994 adalah Institut Pertanian Bogor (IPB). Saat ini, inkubator bisnis IPB atau dikenal dengan IncuBie yang bernaung dibawah Lembaga Penelitian dan Pengabdian Kepada Masyarakat (LPPM) IPB telah mendampingi 249 tenant atau peserta inkubasi/inkubati (inwall tenant dan outwall tenant) dari mahasiswa, staf pengajar IPB, dan masyarakat umum. Pengalaman mengelola inkubator bisnis IPB menjadi pelajaran berharga dalam mewujudkan kinerja inkubator bisnis yang lebih baik.

Berbagai kekuatan dan kelemahan serta peluang dan ancaman harus dikelola dengan baik melalui sebuah strategi yang tepat. Hussey (1999) menjelaskan bahwa perusahaan atau organisasi, baik besar maupun kecil, membutuhkan strategi dalam setiap kegiatannya agar semakin efektif dan efisien. Lalkaka (2002) mengatakan bahwa ke depan, inkubator harus menjunjung profesionalisme pelayanan, mempunyai pendanaan berkelanjutan, pengembangan model inkubator virtual untuk belajar jarak jauh, dan perlunya aliansi antarsesama inkubator.

Penelitian ini bertujuan menyusun strategi pengembangan inkubator bisnis (IncuBie) IPB dengan menganalisis analisis faktor internal dan eksternal yang ada. Analisis strategi itu perlu untuk mengoptimalkan peran dan tujuannya dalam menumbuhkan berbagai wirausaha pemula berbasis teknologi. Perjalanan inkubator bisnis IPB tersebut sangat diperlukan dalam proses pembelajaran untuk meningkatkan perkembangan inkubator bisnis secara nasional.

Studi Vanderstraeten (2015) menyebutkan bahwa pelayanan yang merespon konsumen merupakan mediasi yang sangat penting sehingga inkubator bisnis yang fokus akan meningkatkan daya tahan dan keberhasilan tenant (peserta inkubasi).

\section{METODE PENELITIAN}

Penelitian dilaksanakan di Inkubator Bisnis (IncuBie) IPB di Bogor, Jawa Barat, yang bernaung di bawah Lembaga Penelitian dan Pengabdian kepada Masyarakat (LPPM) IPB. Responden pada penelitian ini dipilih dengan mempertimbangkan pemahaman responden terhadap permasalahan. Sebanyak lima responden pakar dari pihak internal maupun eksternal IncuBie IPB Bogor dengan pertimbangan kapasitas, kemampuan dalam merumuskan perencanaan strategik, dan pengembangan IncuBie IPB. Responden dalam penelitian ini disajikan dalam Tabel 2.

Penelitian ini menggunakan analisis kuantitatif (Quantitative Strategic Planning Matrix/QSPM) maupun kualitatif dengan pendekatan konsep-konsep manajemen strategis. Data yang digunakan adalah data primer dan data sekunder. Data primer diperoleh melalui wawancara dengan bantuan kuisoner yang kemudian ditabulasi dan dianalisis secara kualitatif untuk menentukan strategi yang tepat. Sementara data sekunder diperoleh dari internal lembaga, inkubator bisnis perguruan tinggi yang lain, organisasi atau 
kementerian terkait, asosiasi inkubator bisnis, jurnal, dan hasil-hasil penelitian terkait. Penelitian ini menggunakan analisis analisis faktor internal (Internal Factor Evaluation/IFE) dan eksternal (External Factor Evaluation/EFE), merumuskan grand strategy dengan matriks internal-eksternal (IE), analisis SWOT (Strengths-Weakness-Opportunities-Threats), dan QSPM atau Matriks Perencanaan Strategis Kuantitatif. Sistematika penelitian ini dituangkan pada kerangka pemikiran pada Gambar 1.

\section{HASIL}

\section{Perencanaan Strategik Inkubator Bisnis IPB}

IncuBie IPB menjadi salah satu perintis inkubator bisnis di Indonesia sejak 1994 yang dikenal dengan Pusat Inkubator Agribisnis dan Agroindustri (PIAAIPB). Dalam perkembangannya, pada 2005 PIAAIPB berubah nama menjadi Pusat Penelitian dan Pengembangan Kewirausahaan IPB (P3K-IPB).
Dalam rangka meningkatkan kapasitas kelembagaan agar menjadi pusat inkubator bisnis dan semakin meningkatnya kemampuannya dalam mengembangan kewirausahaan maka sejak tahun 2011 berkembang menjadi Pusat Inkubator Bisnis dan Pengembangan Kewirausahaan atau IncuBie IPB. Jamaran (2009) mengatakan pengembangan jaringan inkubator bisnis berbasis teknologi layak untuk dipertimbangkan sebagai salah satu kegiatan pengabdian masyarakat bagi institusi pendidikan tinggi.

IncuBie IPB dipimpin seorang kepala pusat dan sekretaris yang dibantu oleh dua kepala divisi, yakni divisi inkubator bisnis dan divisi pengembangan kewirausahaan. Divisi inkubator bisnis sendiri mempunyai seorang manajer dan dua staf, sedangkan divisi pengembangan kewirausahaan hanya memiliki satu orang manajer. Total sumber daya manusia (SDM) yang menjalankan IncuBie IPB saat ini mencapai 14 orang. Struktur kelembagaan IncuBie IPB dapat dilihat pada Gambar 3.

Tabel 2. Daftar nama responden

\begin{tabular}{lcl}
\hline \multicolumn{1}{c}{ Nama responden } & Internal/Eksternal & \multicolumn{1}{c}{ Jabatan } \\
\hline Arif Iman Suroso & Internal & Wakil Rektor IV IPB \\
Memen Suherman & Internal & Kepala IncuBie - LPPM IPB \\
Deva P Almada & Internal & Manajer IncuBie - LPPM IPB \\
Wiwik P Novantadi & Eksternal & Tenant inwall (minuman Palaboo) \\
Asril Fitri Syamas & Eksternal & Ketua Asosiasi Inkubator Bisnis Indonesia (AIBI) \\
\hline
\end{tabular}

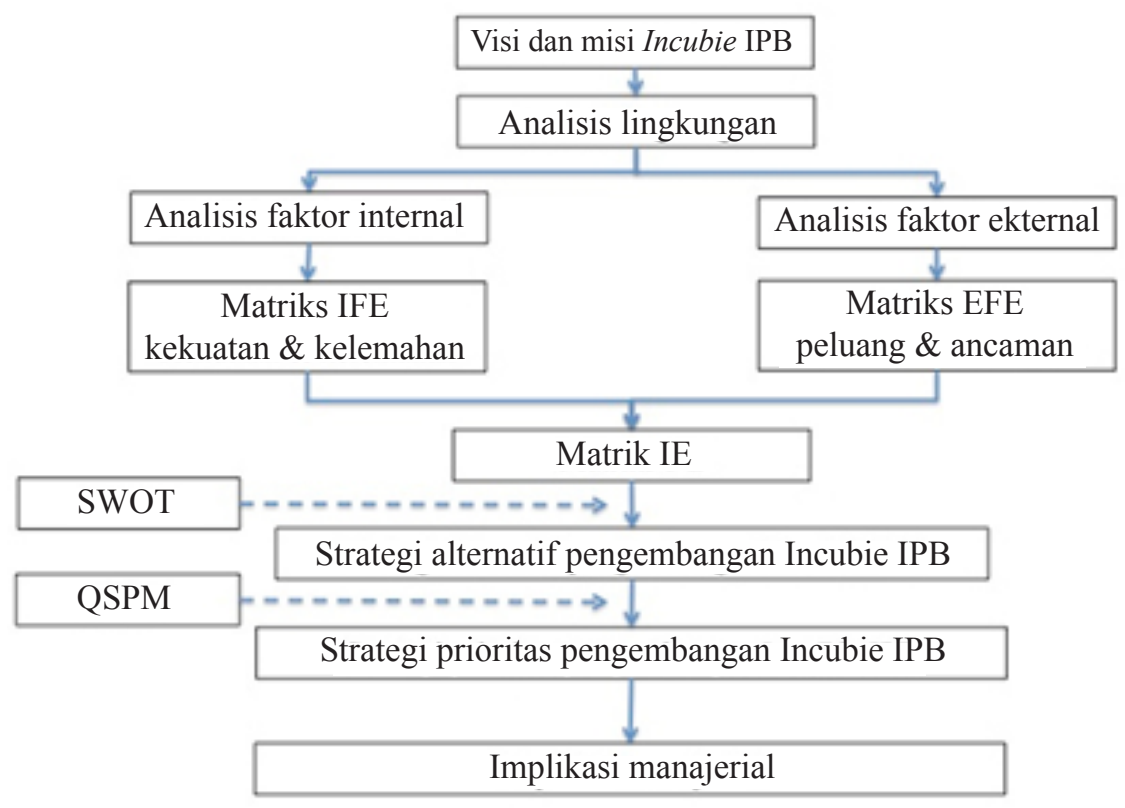

Gambar 1. Kerangka pemikiran penelitian 


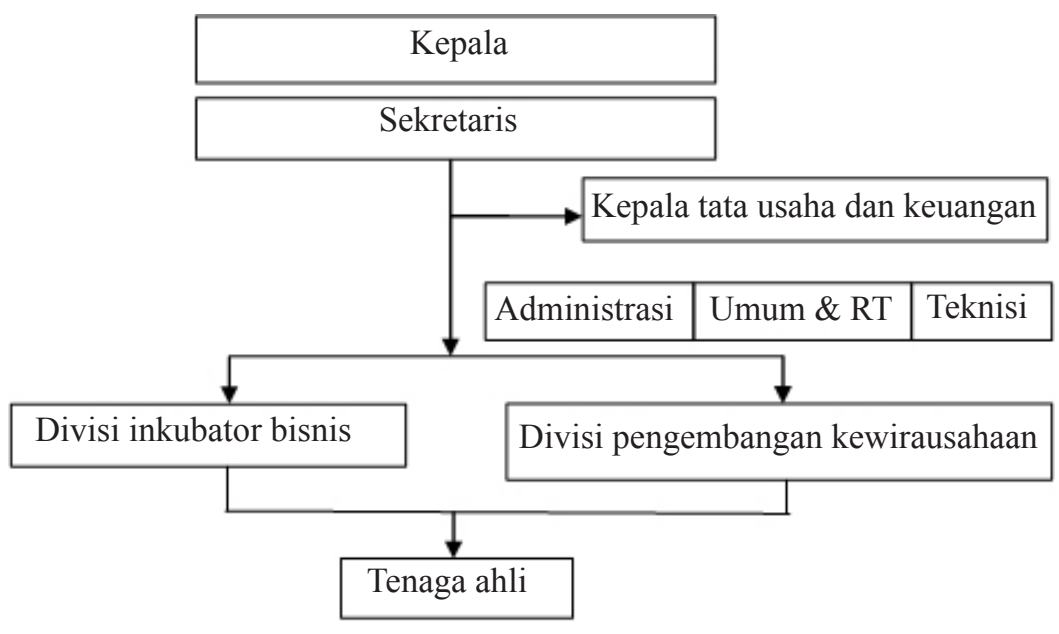

Gambar 3. Struktur IncuBie IPB

IncuBie IPB mempunyai visi menjadi pusat inkubator bisnis dan pengembangan kewirausahaan terkemuka di bidang agribisnis dan agroindustri. Jumlah tenant yang mendapatkan pendampingan (inkubasi) terus meningkat seperti terlihat dalam Tabel 3.

Inkubator bisnis IPB merupakan organisasi yang membutuhkan strategi dalam setiap kegiatannya agar semakin efektif dan efisien. Berbagai kekuatan dan kelemahan serta peluang dan ancaman harus dikelola dengan baik melalui sebuah strategi yang tepat. Hubeis dan Najib (2008) menjelaskan bahwa kekuatan merupakan kondisi internal positif yang memberikan keuntungan relatif dari pesaing kepada perusahaan. Kelemahan adalah faktor-faktor internal negatif yang dapat menghambat atau menghalangi perusahaan untuk mencapai misi, sasaran, dan tujuan perusahaan.

Perencanaan strategik terdiri dari analisis faktor internal (IFE) dan eksternal (EFE) inkubator bisnis IPB sangat dipengaruhi dari perkembangan inkubator bisnis dan pengalaman mendampingi tenant. Faktor internal terdiri kekuatan dan kelemahan, sedangkan faktor eksternal terdiri dari peluang dan ancaman.

\section{Kekuatan}

Kekuatan adalah faktor strategis internal yang dimanfaatkan sebaik-baiknya untuk mencapai tujuan inkubator bisnis. Adapun kekuatan yang dimiliki, adalah:

1. Pengalaman sebagai perintis inkubator bisnis.

2. Kemampuan dan profesionalisme dalam pengelolaan inkubator bisnis.

3. Pendampingan intensif bagi tenant (service).
4. Tempat (space) dan fasilitas bersama (shared) yang cukup.

5. Dukungan akses (support) dan jaringan yang memadai.

Kelemahan

Kelemahan adalah faktor strategi internal yang menghambat dan mengganggu pengembangan inkubator bisnis sehingga perlu mendapat perhatian.

Adapun beberapa kelemahan tersebut seperti:

1. Pendanaan bagi inkubator yang minim dari lembaga induk (IPB).

2. Pencarian alternatif pendanaan bagi tenant masih minim.

3. Legalitas dan status yang belum mendorong kemandirian inkubator bisnis.

4. Kuantitas sumber daya pengelola (manajerial) harus ditingkatkan.

Peluang

Peluang merupakan faktor strategis eksternal yang dimanfaatkan untuk mencapai tujuan inkubator bisnis. Adapun faktor eksternal sebagai berikut:

1. Dukungan regulasi pemerintah terkait inkubator bisnis yang semakin baik.

2. Potensi mendapatkan dukungan dana bagi inkubator masih terbuka.

3. Skema pendanaan khusus bagi inkubator bisnis unggulan dengan kinerja yang baik.

4. Kebutuhan pendampingan wirausaha pemula yang semakin besar.

5. Kebijakan science techno park (STP) yang mendukung inkubator bisnis. 
Tabel 3. Jumlah tenant IncuBie IPB Periode 19952016

\begin{tabular}{cccc}
\hline Tahun & Inwall & Outwall & Jumlah \\
\hline $1995-2000$ & 7 & 20 & 27 \\
$2000-2005$ & 1 & 30 & 31 \\
$2000-2005$ & 1 & 30 & 31 \\
$2005-2010$ & 4 & 35 & 39 \\
$2010-2011$ & - & 7 & 7 \\
$2011-2012$ & 8 & 27 & 35 \\
$2012-2014$ & 15 & 40 & 55 \\
$2014-2016$ & 15 & 40 & 55 \\
\hline Total & 50 & 199 & 249 \\
\hline
\end{tabular}

Ancaman

Ancaman adalah faktor strategis eksternal yang harus disiasati agar upaya mencapai tujuan tetap tercapai. Berikut beberapa ancaman tersebut:

1. Kebijakan pemerintah tentang lembaga intermediasi sejenis inkubator bisnis.

2. Belum ada persamaan persepsi pedoman pembentukan inkubator bisnis nasional.

3. Makin banyaknya lembaga sejenis inkubator bisnis yang mendampingi start-up (perusahaan pemula) terutama dalam bidang-bidang berbasis digital.

4. Gagalnya program inkubator bisnis akibat komitmen lembaga pendiri atau pemilik inkubator binsis yang kurang kuat.

5. Minimnya SDM yang handal dan profesional dalam pengelolaan inkubator bisnis baik dari pemerintah, swasta, maupun perguruan tinggi.

\section{Matriks Internal-Eksternal (IE)}

Analisis faktor internal (IFE) dan eksternal (EFE) yang sudah dirumuskan lalu dilakukan pembobotan sehingga setiap faktor tersebut mempunyai skor terbobot lengkap. Setelah dilakukan pemeringkatan (rating) maka diperoleh skor dari IFE dan EFE tersebut. Gabungan matriks IFE dan EFE menghasilkan matriks internal dan eksternal (IE) berisikan sembilan macam sel yang memperlihatkan kombinasi total nilai terboboti dari matriks IFE dan EFE. Dengan menggunakan matriks IE, pemetaan skor itu menunjukkan posisi dari inkubator bisnis IPB. Tujuan dari matriks IE untuk memperoleh grand strategy sehingga perusahaan atau organisasi bisa menentukan langkah yang harus disiapkan. Matriks ini juga memudahkan proses penentuan dan pemilihan alternatif strategi yang akan diterapkan.
Hasil pemetaan matriks internal eksternal dengan skor terbobot menunjukkan bahwa pengembangan inkubator bisnis IPB berada pada sel II dengan skor 2,81; 3,05 (Gambar 4). Artinya strategi pengembangan inkubator bisnis IPB berada pada tingkat tumbuh dan membangun (David, 2006).

\section{Analisis Alternatif Strategi dengan Matriks SWOT}

Alternatif strategi pengembangan inkubator bisnis IPB dilakukan dengan pendekatan analisis matrisk SWOT. Hasil strategi yang dirumuskan pada matriks SWOT ini merupakan tindak lanjut dari grand strategy dari matriks IE. Empat strategi utama yang dihasilkan yaitu strategi mencocokkan kekuatan dengan peluang (SO), kekuatan dengan ancaman (ST), kelemahan dengan peluang (WO), serta kelemahan dengan ancaman (WT) (David, 2009). Adapun alternatif strategi untuk meningkatkan pengembangan inkubator bisnis IPB adalah sebagai berikut:

\section{Strategi SO}

Strategi ini merupakan strategi mengelola sejumlah kekuatan untuk memanfaatkan peluang yang ada. Dari hasil analisis, rumusan strateginya adalah meningkatkan dukungan dengan implementasi regulasi dan skema pembiayaan khusus bagi inkubator bisnis yang berbasis kinerja dan pelayanan pada tenant.

\section{Strategi ST}

Strategi ini memanfaatkan kekuatan untuk mengantisipasi ancaman dalam pengembangan inkubator bisnis. Adapun rumusan strateginya adalah profesionalisme dan pengalaman menjadi model untuk meningkatkan persamaan persepsi dalam mewujudkan inkubator bisnis yang ideal.

\section{Strategi WO}

Formulasi strategi ini memanfaatkan peluang dengan meminimalkan kelemahan. Rumusan strategi ini adalah mendorong kemandirian inkubator bisnis dan dukungan bagi tenant melalui kebijakan STP. 


\section{Strategi WT}

Strategi ini merupakan strategi yang meminimalkan kelemahan dan menghindari ancaman. Rumusan strategi meningkatkan komitmen lembaga pendiri/ pemilik inkubator bisnis dengan legalitas yang memadai, kapasitas SDM yang sesuai, dan membantu alternatif pendanaan tenant. Alternatif strategi untuk meningkatkan pengembangan inkubator bisnis IPB diperlihatkan dalam Gambar 5.

Total Nilai IFE yang diberi Bobot

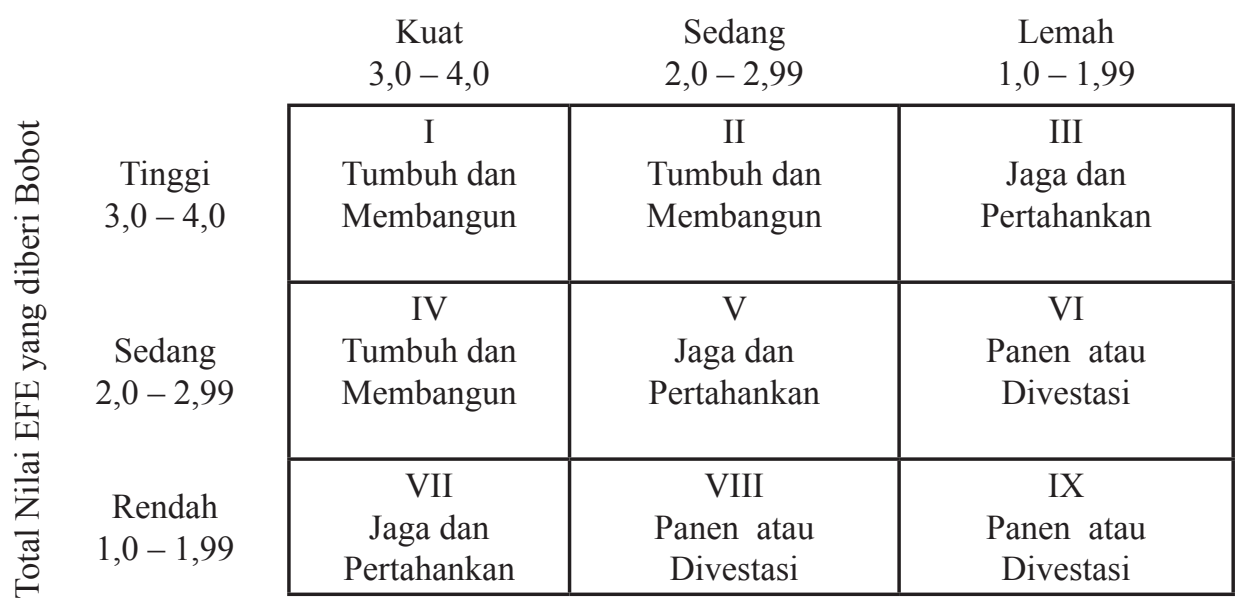

Gambar 4. Pemetaan matriks Internal Eksternal (IE)

\begin{tabular}{|c|c|c|}
\hline & $\begin{array}{l}\text { Kekuatan (S) } \\
\text { 1.Pengalaman sebagai perintis } \\
\text { inkubator bisnis } \\
\text { 2.Kemampuan (profesionalisme) } \\
\text { mengelola inkubator bisnis } \\
\text { 3.Pendampingan intensif bagi tenant } \\
\text { (service) } \\
\text { 4.Tempat (space) dan fasilitas bersama } \\
\text { 5.Dukungan akses (support) dan } \\
\text { jaringan }\end{array}$ & $\begin{array}{l}\text { Kelemahan }(\mathrm{W}) \\
\text { 1.Pendanaan inkubator yang minim } \\
\text { dari lembaga induk } \\
\text { 2.Pencarian alternatif pendanaan tenant } \\
\text { terbatas } \\
\text { 3.Legalitas dan status belum } \\
\text { mendorong kemandirian } \\
\text { 4.Jumlah sumber daya pengelola } \\
\text { inkubator masih rendah (manajerial) }\end{array}$ \\
\hline $\begin{array}{l}\text { Peluang }(\mathrm{O}) \\
\text { 1.Dukungan regulasi pemerintah } \\
\text { 2.Potensi dukungan dana bagi } \\
\text { inkubator } \\
\text { 3.Perlu skema pendanaan khusus } \\
\text { berbasis kinerja } \\
\text { 4.Kebutuhan pendampingan wirausaha } \\
\text { 5.Science techno park (STP) } \\
\text { mendukung inkubator bisnis }\end{array}$ & $\begin{array}{l}\text { Strategi SO } \\
\text { Meningkatkan dukungan dengan } \\
\text { implementasi regulasi dan skema } \\
\text { pembiayaan khusus bagi inkubator } \\
\text { bisnis berbasis kinerja dan pelayanan } \\
\text { tenant (S2, S3, O1, O2, O3, O4) }\end{array}$ & $\begin{array}{l}\text { Strategi WO } \\
\text { Mendorong kemandirian inkubator } \\
\text { bisnis dan dukungan bagi tenant } \\
\text { melalui kebijakan STP yang sudah } \\
\text { dicanangkan pemerintah saat ini (W1, } \\
\text { W2, O1, O5) }\end{array}$ \\
\hline $\begin{array}{l}\text { Ancaman }(\mathrm{T}) \\
\text { 1.Kebijakan lembaga intermediasi } \\
\text { sejenis inkubator bisnis } \\
\text { 2.Belum ada persamaan persepsi } \\
\text { pembentukan inkubator bisnis } \\
\text { 3.Lembaga sejenis inkubator bisnis } \\
\text { yang mendampingi start up digital } \\
\text { 4.Kurangnya komitmen lembaga } \\
\text { pendiri/pemilik inkubator bisnis } \\
\text { 5.Minimnya pengelola inkubator bisnis }\end{array}$ & $\begin{array}{l}\text { Strategi ST } \\
\text { Profesionalisme dan pengalaman } \\
\text { menjadi model untuk meningkatkan } \\
\text { persamaan persepsi dalam } \\
\text { mewujudkan inkubator bisnis yang } \\
\text { ideal (S1, S2, S4, S5, T1, T2) }\end{array}$ & $\begin{array}{l}\quad \text { Strategi WT } \\
\text { Meningkatkan komitmen lembaga } \\
\text { pendiri/pemilik inkubator bisnis } \\
\text { dengan legalitas yang memadai, } \\
\text { kapasitas SDM yang sesuai, dan } \\
\text { membantu alternatif pendanaan tenant } \\
(\mathrm{W} 3, \mathrm{~W} 4, \mathrm{~T} 4, \mathrm{~T} 5)\end{array}$ \\
\hline
\end{tabular}




\section{Analisis QSPM}

Quantitative Strategic Planning Matrix (QSPM) merupakan alat yang memungkinkan penyusun strategi mengevaluasi strategi yang telah dirumuskan secara obyektif menurut faktor-faktor internal dan eksternal yang telah diidentifikasi sebelumnya (David, 2009). Strategi-strategi yang tercipta menurut posisi pada matriks IE dan dirumuskan lebih mendalam pada matriks SWOT dievaluasi apakah menarik untuk menghadapi peluang dan ancaman yang dihadapi inkubator bisnis. Hasil akhir analisis QSPM berupa Total Attractiveness Score (TAS) atau total skor daya tarik yang merupakan penjumlahan hasil perkalian rata-rata nilai daya tarik tertentu dengan rata-rata bobot faktor internal dan eksternal.
Tabel 5 menunjukkan total nilai daya tarik (sum total attractive score/STAS) tertinggi pada strategi SO mencapai 7,05, yakni meningkatkan dukungan melalui implementasi regulasi dan skema pembiayaan khusus bagi inkubator bisnis berbasis kinerja dan pelayanan tenant. Nilai STAS tertinggi kedua adalah strategi strategi WO sebesar 6,18, yakni mendorong kemandirian inkubator bisnis dan dukungan bagi tenant melalui kebijakan STP yang dicanangkan pemerintah.

Kemudian peringkat ketiga pada strategi ST sebesar 5,87, yakni profesionalisme dan pengalaman menjadi model untuk meningkatkan persamaan persepsi dalam mewujudkan inkubator bisnis yang ideal. Lalu peringkat keempat strategi WT dengan nilai 5,67, yakni meningkatkan komitmen lembaga pendiri/pemilik inkubator bisnis dengan legalitas yang memadai, kapasitas SDM yang sesuai, dan membantu alternatif pendanaan tenant.

Tabel 5. Analisis QSPM strategi pengembangan inkubator bisnis IPB

\begin{tabular}{|c|c|c|c|c|c|c|c|c|c|}
\hline \multirow{3}{*}{ Faktor strategi } & \multirow{3}{*}{ Bobot } & \multicolumn{8}{|c|}{ Strategi } \\
\hline & & \multicolumn{2}{|c|}{ SO } & \multicolumn{2}{|c|}{ ST } & \multicolumn{2}{|c|}{ WO } & \multicolumn{2}{|c|}{ WT } \\
\hline & & AS & TAS & $\mathrm{AS}$ & TAS & $\mathrm{AS}$ & TAS & $\mathrm{AS}$ & TAS \\
\hline \multicolumn{10}{|l|}{ Kekuatan } \\
\hline Pengalaman sebagai perintis inkubator bisnis & 0,11 & 3,8 & 0,42 & 2,8 & 0,31 & 3,2 & 0,35 & 2,2 & 0,24 \\
\hline Kemampuan mengelola inkubator bisnis & 0,10 & 3,6 & 0,36 & 3,4 & 0,34 & 3,2 & 0,32 & 3,4 & 0,34 \\
\hline Pendampingan intensif bagi tenant (service) & 0,13 & 3,8 & 0,49 & 2,8 & 0,36 & 3,0 & 0,39 & 2,4 & 0,31 \\
\hline Tempat (space) dan fasilitas bersama & 0,12 & 3,2 & 0,38 & 2,8 & 0,34 & 2,2 & 0,26 & 2,4 & 0,29 \\
\hline Dukungan akses (support) dan jaringan & 0,11 & 3,8 & 0,42 & 3,0 & 0,33 & 2,8 & 0,31 & 2,4 & 0,26 \\
\hline \multicolumn{10}{|l|}{ Kelemahan } \\
\hline Pendanaan inkubator yang minim dari lembaga induk & 0,09 & 3,0 & 0,27 & 2,2 & 0,20 & 3,2 & 0,29 & 3,0 & 0,27 \\
\hline Pencarian alternatif pendanaan tenant masih terbatas & 0,11 & 3,6 & 0,40 & 2,6 & 0,29 & 3,0 & 0,33 & 3,2 & 0,35 \\
\hline Legalitas dan status belum mendorong kemandirian & 0,13 & 3,2 & 0,42 & 3,0 & 0,39 & 3,4 & 0,44 & 2,2 & 0,29 \\
\hline Jumlah sumber daya pengelola inkubator masih rendah & 0,11 & 3,0 & 0,33 & 2,8 & 0,31 & 3,0 & 0,33 & 2,4 & 0,26 \\
\hline \multicolumn{10}{|l|}{ Peluang } \\
\hline Dukungan regulasi pemerintah & 0,17 & 3,2 & 0,54 & 2,8 & 0,48 & 3,5 & 0,60 & 2,4 & 0,41 \\
\hline Potensi dukungan dana bagi inkubator & 0,11 & 3,8 & 0,42 & 3,0 & 0,33 & 3,4 & 0,37 & 3,4 & 0,37 \\
\hline Perlu skema pendanaan khusus berbasis kinerja & 0,08 & 3,8 & 0,30 & 2,8 & 0,22 & 3,0 & 0,24 & 3,0 & 0,24 \\
\hline Kebutuhan pendampingan wirausaha & 0,12 & 3,2 & 0,38 & 2,6 & 0,31 & 3,0 & 0,36 & 3,0 & 0,36 \\
\hline Science techno park (STP) mendukung inkubator bisnis & 0,10 & 3,0 & 0,30 & 2,4 & 0,24 & 3,0 & 0,30 & 3,8 & 0,38 \\
\hline \multicolumn{10}{|l|}{ Ancaman } \\
\hline Kebijakan lembaga intermediasi sejenis inkubator bisnis & 0,09 & 3,6 & 0,32 & 2,8 & 0,25 & 3,4 & 0,31 & 2,4 & 0,22 \\
\hline Belum ada persamaan persepsi pembentukan inkubator & 0,08 & 3,6 & 0,29 & 3,6 & 0,29 & 3,4 & 0,27 & 3,2 & 0,26 \\
\hline $\begin{array}{l}\text { Lembaga sejenis inkubator bisnis yang mendampingi start } \\
\text { up berbasis digital }\end{array}$ & 0,12 & 3,4 & 0,41 & 2,6 & 0,31 & 2,0 & 0,24 & 2,0 & 0,24 \\
\hline $\begin{array}{l}\text { Kurangnya komitmen lembaga pendiri/pemilik inkubator } \\
\text { bisnis }\end{array}$ & 0,08 & 3,2 & 0,26 & 3,0 & 0,24 & 2,2 & 0,18 & 3,6 & 0,29 \\
\hline Minimnya pengelola inkubator bisnis & 0,11 & 3,4 & 0,37 & 3,0 & 0,33 & 2,6 & 0,29 & 2,6 & 0,29 \\
\hline Total (STAS) & & & 7,05 & & 5,87 & & 6,18 & & 5,67 \\
\hline
\end{tabular}


Pemilihan strategi SO menekankan pada aspek skema pendanaan khusus dan implementasi regulasi yang sudah ada. Sebagaimana evaluasi yang dilakukan kelompok kerja pengembangan inkubator wirausaha dariKementerian Perekonomian menyebutkan beberapa rekomendasi. Salah satunya perlu skema pembiayaan inkubator wirausaha oleh lembaga yang bertanggung jawab tentang pendirian inkubator di Indonesia. Bentuk dan mekanismenya masih perlu didalami sehingga perlu mempertimbangakan berbagai aspek.

Strategi prioritas kedua adalah mendorong kemandirian inkubator bisnis dan dukungan bagi tenant melalui kebijakan STP. Kebijakan STP yang tengah digalakkan pemerintah saat ini menjadi peluang mengembangkan inkubator bisnis. Dalam STP memerlukan proses inkubasi atas inovasi teknologi yang hendak dikomersilkan.

Untuk strategi prioritas ketiga adalah profesionalisme dan pengalaman menjadi model untuk meningkatkan persamaan persepsi dalam mewujudkan inkubator bisnis ideal. Strategi ini cukup penting karena pengalaman dari inkubator bisnis IPB bisa menjadi salah satu model untuk menjadi acuan dan menyamakan persepsi.

Strategi prioritas keempat merupakan model defensif dengan meminimalkan kelemahan dan menghindari ancaman. Dengan analisis yang dilakukan maka rumusan strategi yang tepat adalah meningkatkan komitmen lembaga pendiri/pemilik IB dengan legalitas yang memadai, kapasitas SDM yang sesuai, dan membantu alternatif pendanaan tenant.

\section{Implikasi Manajerial}

Setiap strategi yang dihasilkan tentu mempunyai implikasi manajerial. Dengan strategi prioritas pertama yang diperlukan dalam pengembangan inkubator bisnis adalah mendorong terwujudnya skema pendanaan berbasis kinerja. Langkah itu dimulai dengan menyusun parameter atas kinerja inkubator bisnis unggulan, sekaligus tahapan dan mekanisme dalam skema pendanaan yang ditawarkan. Program pemerintah dalam membantu inkubator bisnis sebaiknya menggarap model dan skema pembiayaan yang dimaksud. Inkubator bisnis IPB tentu bisa menjadi salah satu pilot project sekaligus menjadi pembelajaran bagi pihak-pihak lain.
Dalam strategi kedua yang bermaksud mendorong kemandirian inkubator bisnis dan dukungan bagi tenant melalui kebijakan STP, perlu diatur batasan antara STP ideal dengan posisi dan peran inkubator bisnis. Para pengelolayang sudah berpengalaman perlu memberikan masukan agar implementasi STP semakin memperkuat inkubator bisnis. IPB Science Techno Park merupakan salah satu dari program STP nasional perlu didukung dengan inkubator binsis IPB yang sudah lama dirintis, berpengalaman menampingi tenant, memiliki kapasitas dan fasilitas.

Untuk strategi ketiga, yakni mendorong sebuah model dan meningkatkan persamaan persepsi dalam mewujudkan inkubator bisnis ideal maka perlu sejumlah pilot project dari pemerintah daerah dan pelaku usaha. Pengalaman sejumlah inkubator unggulan dari perguruan tinggi, termasuk IncuBie IPB, bisa dijadikan acuan bagi setiap daerah atau pelaku usaha swasta.

Strategi keempat untuk meningkatkan komitmen lembaga pendiri/pemilik IB dengan legalitas yang memadai, kapasitas SDM yang sesuai, dan membantu alternatif pendanaan tenant. Implikasi manajerial dari strategi ini adalah mendorong lembaga induk/pemilik inkubator bisnis untuk memastikan posisi dan legalitas. Hal tersebut harus ditunjukkan dengan ketersediaan sumber daya, dukungan dana, dan fasilitas yang tersedia.

\section{KESIMPULAN DAN SARAN}

\section{Kesimpulan}

Inkubator bisnis IPB memiliki faktor internal yang kuat dan memiliki respon yang baik terhadap faktor eksternal. Faktor internal terdiri dari kekuatan dan kelemahan, sedangkan faktor eksternal terdiri peluang dan ancaman. Dari analisis IFE, faktor strategis internal yang menjadi kekuatan paling berpengaruh adalah pendampingan intensif bagi tenant (service), sementara kelemahan yang juga paling berpengaruh adalah legalitas dan status kelembagaan. Hasil analisis EFE menunjukkan bahwa peluang utama dari inkubator bisnis IPB adalah dukungan regulasi Peraturan Presiden (Perpres) 27/2013 tentang Pengembangan Inkubator Wirausaha yang semakin baik, sedangkan ancaman yang sangat berpengaruh adalah semakin banyaknya lembaga sejenis inkubator bisnis yang mendampingi perusahaan pemula (start-up). 
Dari analisis matriks IE menunjukkan bahwa inkubator bisnis IPB berada pada sel II, yakni posisi tumbuh dan membangun (grow and build). Posisi ini merupakan strategi besar (grand strategy) yang sangat membantu dalam penentuan berbagai alternatif strategi dengan analisis SWOT yang akan menghasilkan empat strategi utama.

Hasil analisis matriks QSPM menunjukkan bahwa strategi yang direkomendasikan dari beragam alternatif yang diperoleh adalah meningkatkan dukungan melalui implementasi regulasi dan skema pembiayaan khusus bagi inkubator bisnis berbasis kinerja dan pelayanan tenant. Ini merupakan strategi SO dengan total nilai daya tarik (STAS) tertinggi mencapai 7,05.

\section{Saran}

Berdasarkan proses dan penelitian yang telah dilakukan disarankan agar penelitian selanjutnya lebih mendalami implementasi atas rekomendasi strategi yang ada. Hal itu untuk mempertajam skema pendanaan bagi inkubator bisnis dan perlunya menelaah kinerja dari inkubator bisnis yang perlu didukung. Selain itu, perlu juga memberikan evaluasi atas kebijakan STP terkait dengan berbagai program inkubator bisnis yang sudah berjalan. Hal itu sangat penting agar tidak ada tumpang tindih dalam pelaksanaannya dan lebih bermanfaat bagi pengembangan usaha pemula.

\section{DAFTAR PUSTAKA}

Bruneel J. 2012. The evolution of business incubators: comparing demand and supply of business incubation services across different incubator generations. Technovation 32: 110-112. https:// doi.org/10.1016/j.technovation.2011.11.003.

David FR. 2009. Konsep Manajemen Strategis. (Terjemahan). Edisi Kedua Belas. Jakarta: Salemba Empat.
Dewi YA. 2012. Inovasi spesifik lokasi untuk inkubator teknologi mendukung pengembangan ekonomi lokal. Jurnal Analisis Kebijakan Pertanian 10(4): 299-312. https://doi.org/10.21082/akp. v10n4.2012.299-312.

Hasbullah R. 2014. Model pendampingan UMKM pangan melalui inkubator bisnis perguruan tinggi. Jurnal Ilmu Pertanian Indonesia 19(1): 43-49.

Hussey D. 1999. Strategic and Planning. New York: John Wiley \& Sons.LTD.

Jamaran I. 2009. Studi awal pengembangan Jaringan inkubator teknologi dan bisnis pada institusi penidikan tinggi di Indonesia. Jurnal Matematika, Sains, dan Teknologi 9(1): 47-53.

Lalkaka R. 2002. Technology business incubators to help build an innovation-based economy. Journal of Change Management 3(2): 167-176. https://doi.org/10.1080/714042533.

Presiden Republik Indonesia. 2013. Peraturan Presiden Republik Indonesia Nomor 27 Tahun 2013 tentang Pengembangan Inkubator Wirausaha. Jakarta.

Purwadaria, HK. 2012. Pedoman dan Pengelolaan Inkubator Bisnis Perguruan Tinggi. Jakarta. KemenKopUKM.

Sumodiningrat G, Ari W. 2015. Menuju Ekonomi Berdikari - Pemberdayaan UMKM dengan Konsep OPOP - OVOP - OVOC.Yogyakarta: Penerbit Media Pressindo.

Tietz G. 2015. Business incubators in Brazil: main gaps to be explored by academic researchers. Journal of Technology Management \& Innovation 10(4): 18-27. https://doi.org/10.4067/S071827242015000400003.

Vanderstraeten J. 2015. Being flexible through customization -The impact of incubator focus and customization strategies on incubatee survival and growth. Journal of Engineering Technology Management 41: 45-64. https://doi. org/10.1016/j.jengtecman.2016.06.003. 